\title{
A toolbox for epitope-tagging and genome-wide location analysis in Candida albicans

\author{
Hugo Lavoie ${ }^{1,2}$, Adnane Sellam ${ }^{1,3}$, Christopher Askew ${ }^{1,2}$, André Nantel ${ }^{1,3}$ and \\ Malcolm Whiteway*1,2
} \author{
Canada \\ Email: Hugo Lavoie - hugo.lavoie@cnrc-nrc.gc.ca; Adnane Sellam - adnane.sellam@cnrc-nrc.gc.ca; \\ Christopher Askew - christopher.Askew@cnrc-nrc.gc.ca; André Nantel - andre.nantel@nrc-cnrc.gc.ca; \\ Malcolm Whiteway* - malcolm.Whiteway@cnrc-nrc.gc.ca \\ * Corresponding author
}

Address: ${ }^{1}$ Biotechnology Research Institute, National Research Council, Montreal, Quebec, H4P 2R2, Canada, ${ }^{2}$ Department of Biology, McGill University, Montreal, Quebec, H3A 1B1, Canada and 32Department of Anatomy and Cell Biology, McGill University, Montreal, Quebec, H3A 1B1,

Published: 2 December 2008

BMC Genomics 2008, 9:578 doi:10.1/86/147|-2164-9-578
Received: 5 September 2008

Accepted: 2 December 2008

This article is available from: http://www.biomedcentral.com/I47I-2/64/9/578

(C) 2008 Lavoie et al; licensee BioMed Central Ltd.

This is an Open Access article distributed under the terms of the Creative Commons Attribution License (http://creativecommons.org/licenses/by/2.0), which permits unrestricted use, distribution, and reproduction in any medium, provided the original work is properly cited.

\begin{abstract}
Background: Candida albicans is a diploid pathogenic fungus not yet amenable to routine genetic investigations. Understanding aspects of the regulation of its biological functions and the assembly of its protein complexes would lead to further insight into the biology of this common diseasecausing microbial agent.

Results: We have developed a toolbox allowing in vivo protein tagging by PCR-mediated homologous recombination with TAP, HA and MYC tags. The transformation cassettes were designed to accommodate a common set of integration primers. The tagged proteins can be used to perform tandem affinity purification (TAP) or chromatin immunoprecipitation coupled with microarray analysis (ChIP-CHIP). Tandem affinity purification of $C$. albicans NopI revealed the high conservation of the small processome composition in yeasts. Data obtained with in vivo TAP-tagged Tbfl, Cbfl and $\mathrm{Mcml}$ recapitulates previously published genome-wide location profiling by ChIP$\mathrm{CHIP}$. We also designed a new reporter system for in vivo analysis of transcriptional activity of gene loci in C. albicans.
\end{abstract}

Conclusion: This toolbox provides a basic setup to perform purification of protein complexes and increase the number of annotated transcriptional regulators and genetic circuits in C. albicans.

\section{Background}

Candida albicans is an important human fungal pathogen because of its clinical significance as well as its use as an experimental model for scientific investigation [1]. This opportunistic pathogen is a natural component of the human skin, gastrointestinal and genitourinary flora, but it can sporadically cause a variety of infections. Although many Candida infections are not life-threatening (oral thrush and vaginal candidiasis, for example), immunosuppressed patients can be subjected to potentially lethal systemic infections, and therefore Candida infections are a major public health concern $[2,3]$. C. albicans can also colonize various biomaterials, and readily forms dense, complex biofilms that are resistant to most antifungal agents. Because of the challenges of drug resistance [4] and the eukaryotic nature of C. albicans that makes it similar to its 
human host, extensive efforts are underway to identify new drug targets for therapeutic intervention; many of these take advantage of tools from the genomic era [5-7]. Because of some of its unique biological features, C. albicans is also becoming attractive to studies of more fundamental aspects of genome maintenance, regulatory biology and morphogenesis [8-10].

The diploid nature and the absence of a complete sexual cycle in C. albicans reduces the ease with which genetic manipulations can be achieved [11]. Therefore, biochemical, cell biological and genomic analyses of gene products provide alternate strategies to improve our understanding of this pathogen. In particular, obtaining a better insight into how specific protein complexes assemble in C. albicans would help define targets for drug development. For example, the large-scale definition of protein complexes by tandem affinity purification (TAP), as it was previously done in S. cerevisiae $[12,13]$, should reveal the architecture of biochemical networks and protein machines specific to C. albicans. This approach would also give insight into the evolution of protein complexes in ascomycetes. As well, the availability of tools allowing comprehensive functional analysis of transcription factors (TFs) on a genomewide scale could enhance cellular studies. Genome-wide location analysis, or ChIP-CHIP analysis (chromatin immunoprecipitation (ChIP) followed by DNA microarrays (CHIP)) allows the identification of direct targets of a defined TF on a genomic scale [14]. This approach has been comprehensively applied to the model budding yeast $S$. cerevisiae in order to map its transcriptional regulatory network $[15,16]$. While first developed in S. cerevisiae, ChIP-CHIP has since been applied to other organisms including $C$. albicans $[17,18]$. In addition, $C$. albicans has recently been established as an interesting model organism for the study of the evolution of transcriptional regulatory networks. In fact, it appears that $C$. albicans differs significantly in its mode of gene regulation from the well-characterized $S$. cerevisiae transcriptional circuits. It has recently served as a comparative system for studying the evolution of the mating type control circuit and the evolution of ribosomal protein (RP) regulation $[19,20]$. Furthermore, changes occuring in the activity of TFs seem to account for part of acquired drug resistance in C. albicans $[21,22]$. Moreover, several TFs play a critical role in the $C$. albicans morphological transitions and in biofilm formation $[10,23]$. Therefore, a detailed understanding of the transcriptional regulation mechanisms in C. albicans would be valuable for basic research purposes as well as for improving our understanding of drug resistance and for aiding in the development of new antifungals.

Here we report the construction of a new set of PCR-based epitope-tagging vectors for C. albicans that is successfully applied to perform a biochemical characterization of the small processome subunit via Nop1 tandem affinity purification as well as genome-wide location analysis of the model TFs Tbf1, Cbf1 and Mcm1.

\section{Results and discussion \\ A set of PCR cassettes for protein tagging}

The choice of selectable marker genes in our cassettes, URA3, HIS1 and ARG4 was guided by the availability of the C. albicans strains BWP17 and SN76 that have the auxotrophic mutations (ura3/ura3; his1/his1; arg4/ arg4) $[24,25]$. Our cassettes permit the use of a single 120bp primer pair (20 bp of vector sequences and $100 \mathrm{bp}$ from the gene to be tagged) to tag genes with three epitopes (Fig. 1A). In addition, our PCR strategy is compatible with the previously published pFA-XFP-tagging system [26]. With this vector set, the tagged protein is expressed under the control of its own regulatory sequences and chromatin environment and thus at its normal physiological levels, thereby maximizing the biological relevance of biochemical analyses.

The HA and MYC epitope tags have been used to tag proteins in various organisms and for various applications $[27,28]$. They represent highly immunogenic peptides with little biological activity that can then be used in immunoprecipitation/co-immunoprecipitation experiments to validate protein complex formation. The TAP tag was more recently developed in order to obtain high purified protein samples for mass spectrometry analysis of protein complexes [29]. Tagged strains were first validated by PCR and subsequently by western blotting (Fig. 2A and $2 \mathrm{~B})$, and we confirmed that the tagged constructs are easily immunoprecipitated (data not shown). Doubly tagged strains can also be obtained with combinations of selective markers offered by the BWP17 and the SN76 strain backgrounds. We produced Tbf1-HA/Cbf1-Myc and reciprocal tagged stains (Fig. 2C).

\section{Tandem affinity purification of Nopl}

Since its introduction in 1999, the TAP-tag has been used in various organisms to perform protein-complex purifications [29]. In S. cerevisiae, it has been used to assess protein-protein interactions on a large scale $[12,30]$. We performed a standard TAP procedure using the TAPtagged Nop1, a component of the small processome subunit in S. cerevisiae [13]. Mass spectrometric analysis of insolution digested TCA-precipitated proteins after the TAP procedure identified $18 \mathrm{C}$. albicans proteins and in-gel digestion of four SYPRO Ruby stained SDS-PAGE bands led to the identification of an additional protein (Fig. 2D and Table 1). In total, 19 C. albicans proteins were identified, 16 of which are bona fide components of the S. cerevisiae small sub-unit processome (SSU processome) (Table 1 and Fig. 2E) [13]. In addition, three ribosomal 
A)

In vivo epitope tagging

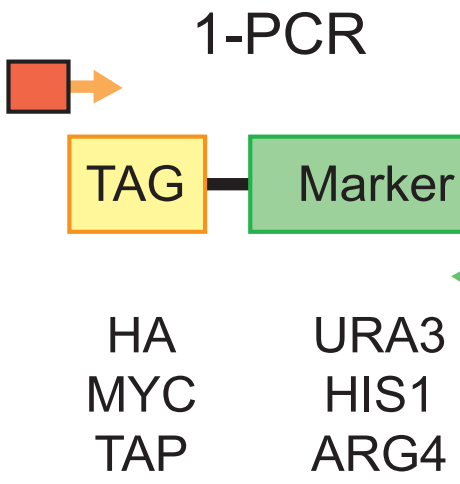

2-Homologous recombination

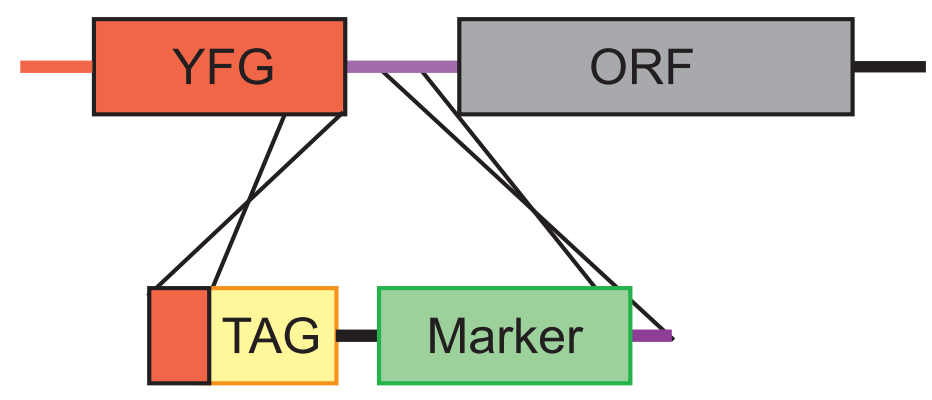

B)

PCR confirmation

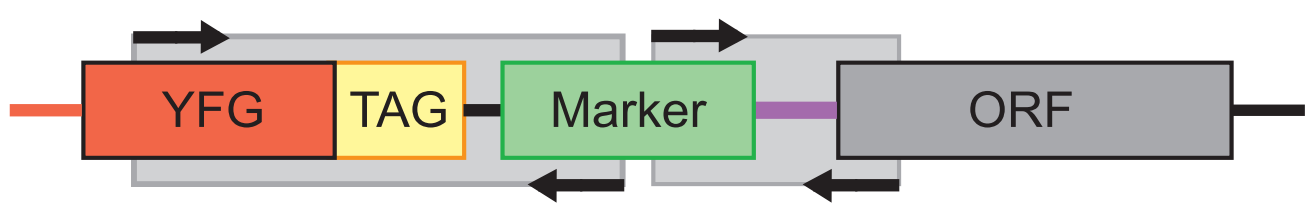

Figure I

Plasmid constructs for in vivo protein tagging in C. albicans. A) Two-step insertion of tags by I- PCR and 2- homologous recombination. B) PCR confirmation of tagged constructs. YFG stands for Your Favorite Gene. 


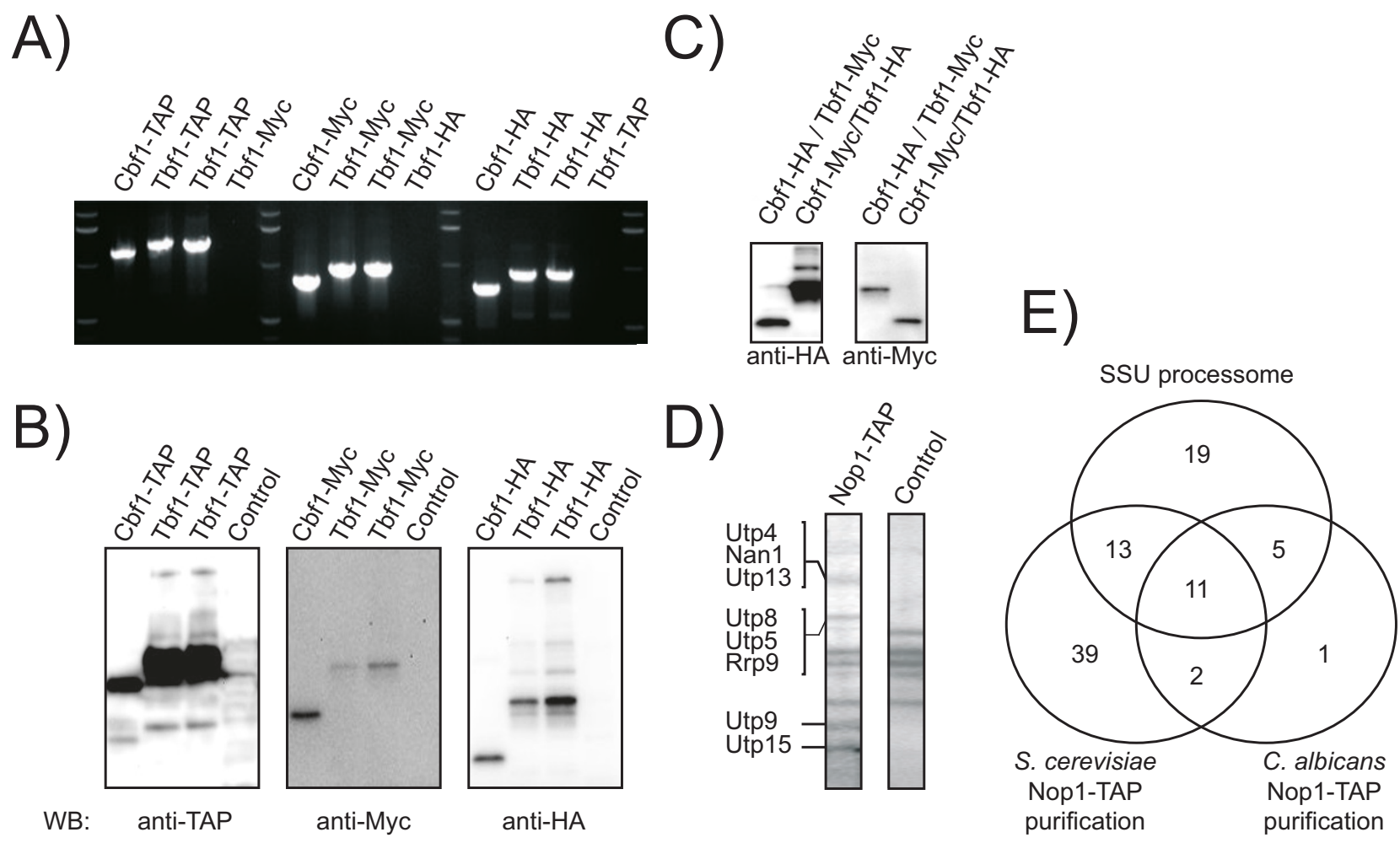

Figure 2

Our new PCR tagging cassettes allow the rapid biochemical analysis of tagged proteins. PCR (A) and Western blot (B) confirmation of TAP, Myc and HA-tagged transcription factors CbfI and TbfI. C) Western blot validation of doubly tagged strains CbfI-HA/TbfI-Myc and CbfI-Myc/TbfI-HA. D) SYPRO Ruby stained SDS-PAGE gel following tandem affinity purification of Nop I-TAP. Proteins identified in each band by in-gel digestion followed by mass spectrometry are identified on the left. E) Venn diagram comparison of Nop I-TAP hits in C. albicans and S. cerevisiae.

proteins were co-purified with Nop1; ribosomal proteins are common false positives in protein complex purification procedures (Table 1)[31]. We compared the coverage generated through our approach to that of the orthologous Nop1-TAP purification in S. cerevisiae. The C. albicans Nop1-TAP bait retrieved 16 proteins (33\%) of the annotated SSU processome subunits while its $S$. cerevisiae ortholog retrieved 24 (50\%) http://www.thebiogrid.org/ SearchResults/summary/32040, so the coverage of the $S$. cerevisiae set was higher. However, the proportion of core components of the SSU processome retrieved in C. albicans $(84 \%)$ surpasses the proportion retrieved in S. cerevisiae by all published affinity-capture followed by mass spectrometry studies (37\%)[32]. It is likely that the stringency of our protocol accounts for the lower coverage and higher specificity of the set of hits retrieved; Modifications of the purification conditions could allow for the desired specificity. Overall, it is apparent that a basic TAP protocol is amenable to C. albicans proteins. This approach will be of great utility in the analysis of function of currently poorly defined proteins and in the study of the evolution of protein complexes in yeasts.

ChIP-CHIP analysis of in vivo tagged transcription factors One potential application of TAP-tagged TFs consists of their use in ChIP-CHIP to map their DNA-binding targets in vivo. ChIP-CHIP was therefore performed for three TAPtagged TFs; Tbf1, Cbf1 and Mcm1. For Tbf1 and Cbf1, the results obtained were compared to previously published data using ectopically expressed Tbf1-HA and Cbf1-HA constructs [20]. The location profiles of TAP-tagged TFs were essentially identical to the previous results and confirmed that the RP regulon is dominated by the Myb transcription factor Tbf1 working in conjunction with Cbf1 (Fig. 3A and 3B) [20].

Genome-wide location of the $S$. cerevisae MADS box cell cycle regulator ortholog $\mathrm{Mcm} 1$ was also investigated in $C$. albicans cells. S. cerevisiae $\mathrm{Mcm} 1$ plays a critical role in the regulation of cell cycle transitions and, more specifically, 
Table I: Mass spectrometry results after Nop I-TAP tandem affinity purification

\begin{tabular}{|c|c|c|c|c|c|c|c|}
\hline $\begin{array}{l}\text { Systematic } \\
\text { name }\end{array}$ & $\begin{array}{l}\text { Common } \\
\text { name }\end{array}$ & Protein Score & $\begin{array}{l}\text { Number of } \\
\text { peptides* }\end{array}$ & Mass (kDa) & $\begin{array}{l}\text { Cellular } \\
\text { component }\end{array}$ & $\begin{array}{l}\text { Biological } \\
\text { process }\end{array}$ & $\begin{array}{l}\text { Molecular } \\
\text { function }\end{array}$ \\
\hline orfl9.7569 & Sikl & 504.3 & 8 & 58 & $\begin{array}{l}\text { small-subunit } \\
\text { processome }\end{array}$ & $\begin{array}{l}\text { rRNA } \\
\text { modification }\end{array}$ & snoRNA binding \\
\hline orfl9.1566 & Utp2I & 337.4 & 7 & 104 & $\begin{array}{l}\text { Small-subunit } \\
\text { processome }\end{array}$ & $\begin{array}{l}\text { rRNA } \\
\text { modification }\end{array}$ & Unknown \\
\hline orfl9.1199 & Nop5 & 327.5 & 6 & 57 & $\begin{array}{l}\text { Small-subunit } \\
\text { processome }\end{array}$ & $\begin{array}{l}\text { rRNA } \\
\text { modification }\end{array}$ & snoRNA binding \\
\hline orf19.7154 & Utp 18 & 208.3 & 4 & 62 & $\begin{array}{l}\text { Small-subunit } \\
\text { processome }\end{array}$ & $\begin{array}{l}\text { rRNA } \\
\text { modification }\end{array}$ & Unknown \\
\hline orfl9.1633 & Utp4 & 206.5 & 4 & 85 & $\begin{array}{l}\text { Small-subunit } \\
\text { processome }\end{array}$ & $\begin{array}{l}\text { rRNA } \\
\text { modification }\end{array}$ & snoRNA binding \\
\hline orfl9.3138 & Nop I* & 186.5 & 3 & 33 & $\begin{array}{l}\text { Small-subunit } \\
\text { processome }\end{array}$ & $\begin{array}{l}\text { rRNA } \\
\text { modification }\end{array}$ & snoRNA binding \\
\hline orfl9.7599 & Utp5 & 174.3 & 4 & 71 & $\begin{array}{l}\text { Small-subunit } \\
\text { processome }\end{array}$ & $\begin{array}{l}\text { rRNA } \\
\text { modification }\end{array}$ & Unknown \\
\hline orfl9.3609 & Utp I5 & 172.8 & 2 & 47 & $\begin{array}{l}\text { Small-subunit } \\
\text { processome }\end{array}$ & $\begin{array}{l}\text { rRNA } \\
\text { modification }\end{array}$ & snoRNA binding \\
\hline orfl9.6710 & Utp9 & 149.8 & 1 & 50 & $\begin{array}{l}\text { Small-subunit } \\
\text { processome }\end{array}$ & $\begin{array}{l}\text { rRNA } \\
\text { modification }\end{array}$ & snoRNA binding \\
\hline orfl9.1601 & Rpl3 & 121.4 & 2 & 44 & $\begin{array}{l}\text { Cytosolic large } \\
\text { ribosomal } \\
\text { subunit }\end{array}$ & translation & $\begin{array}{l}\text { structural } \\
\text { constituent of } \\
\text { ribosome }\end{array}$ \\
\hline orfl9.3430 & Bud2I & 100.9 & 2 & 25 & $\begin{array}{l}\text { Small-subunit } \\
\text { processome }\end{array}$ & $\begin{array}{l}\text { rRNA } \\
\text { modification }\end{array}$ & snoRNA binding \\
\hline orfl9.3276 & Pwp2 & 99.7 & 2 & 104 & $\begin{array}{l}\text { Small-subunit } \\
\text { processome }\end{array}$ & $\begin{array}{l}\text { rRNA } \\
\text { modification }\end{array}$ & snoRNA binding \\
\hline orfl9.2688 & Nan I & 88.7 & 2 & 94 & $\begin{array}{l}\text { Small-subunit } \\
\text { processome }\end{array}$ & $\begin{array}{l}\text { rRNA } \\
\text { modification }\end{array}$ & snoRNA binding \\
\hline orfl9.5436 & Utp8 & 88.5 & I & 81 & $\begin{array}{l}\text { Small-subunit } \\
\text { processome }\end{array}$ & $\begin{array}{l}\text { rRNA } \\
\text { modification }\end{array}$ & snoRNA binding \\
\hline orfl9.5106 & Dip2 & 77.8 & 2 & 110 & $\begin{array}{l}\text { small-subunit } \\
\text { processome }\end{array}$ & $\begin{array}{l}\text { rRNA } \\
\text { modification }\end{array}$ & snoRNA binding \\
\hline orfl9.5225.2 & Rpl27 & 59.7 & I & 16 & $\begin{array}{l}\text { cytosolic large } \\
\text { ribosomal } \\
\text { subunit }\end{array}$ & translation & $\begin{array}{l}\text { structural } \\
\text { constituent of } \\
\text { ribosome }\end{array}$ \\
\hline orfl9.2830 & Rrp9 & 58.8 & 1 & 62 & $\begin{array}{l}\text { small-subunit } \\
\text { processome }\end{array}$ & $\begin{array}{l}\text { rRNA } \\
\text { modification }\end{array}$ & snoRNA binding \\
\hline orfl9.6085 & Rpll6 & 56.9 & 1 & 20 & $\begin{array}{l}\text { cytosolic large } \\
\text { ribosomal } \\
\text { subunit }\end{array}$ & translation & $\begin{array}{l}\text { structural } \\
\text { constituent of } \\
\text { ribosome }\end{array}$ \\
\hline orfl9.4268 & Utpl3** & NA & NA & 90 & $\begin{array}{l}\text { small-subunit } \\
\text { processome }\end{array}$ & $\begin{array}{l}\text { rRNA } \\
\text { modification }\end{array}$ & snoRNA binding \\
\hline
\end{tabular}

* Nopl was the bait in this tandem affinity purification experiment.

** Utp 13 was identified by in-gel but not in-solution digestion. 
of the pre-replication complex (Pre-RC). The Mcm1 para$\log$ Arg80 arose after the whole-genome duplication of the yeast lineage and is involved in the regulation of arginine metabolism genes [8]. The overlap of our $\mathrm{Mcm} 1$ genomewide binding data in yeast state cells with a previously published Mcm 1 ChIP-CHIP done on tiling microarrays is highly significant (pvalue = 2.7E-11) with 198 genes common between studies [8] (Fig. 3D). We confirm that $C$. albicans $\mathrm{Mcm} 1$ occupies the roles of $S$. cerevisiae $\mathrm{Mcm} 1$

A)

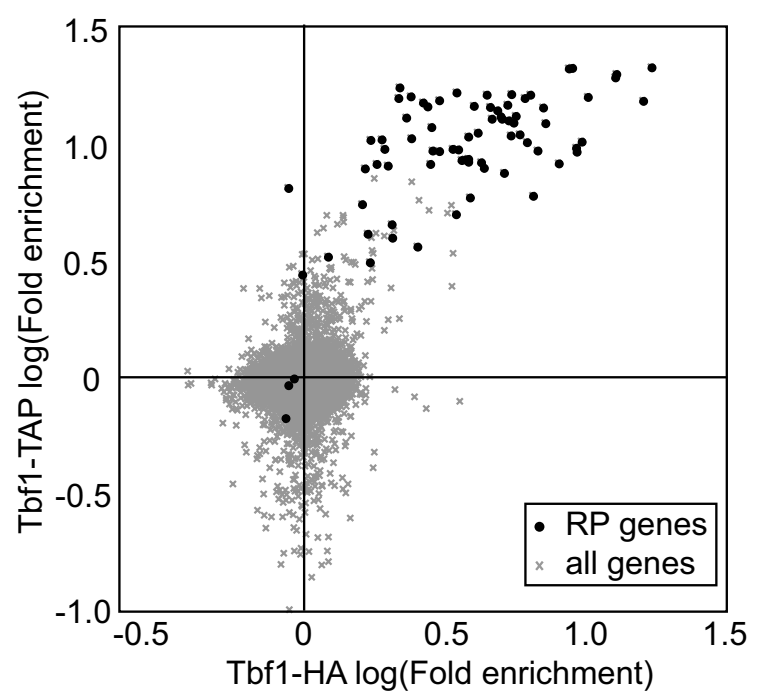

B)

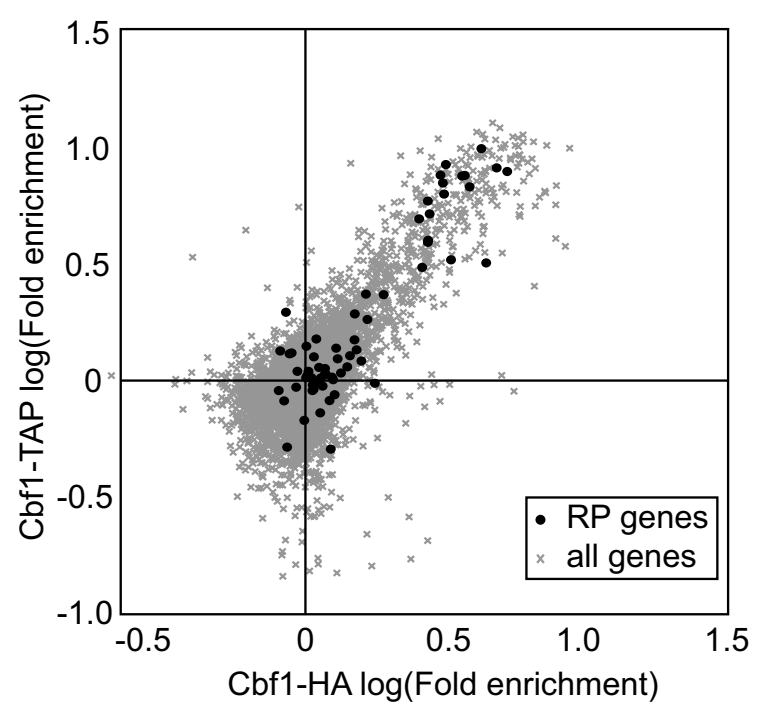

and Arg80 since genes from the arginine biosynthesis pathway such as $A R G 3 / 4 / 5-6 / 8, C A R 1$ and the zinc transcription factor $A R G 81$ are enriched in our set (pvalue = 5.52E-07; Table 2). Genes involved in the biosynthesis of the other basic amino acid, lysine (LYS1/9/21/22 and 144), and also catabolic proline processing (PUT1 and 2) are also enriched in ours and Tuch et al. (2008) gene lists (Table 2). In addition, we confirm that $\mathrm{Mcm} 1$ binds strongly to its own promoter (Table 2). We finally confirm

C)

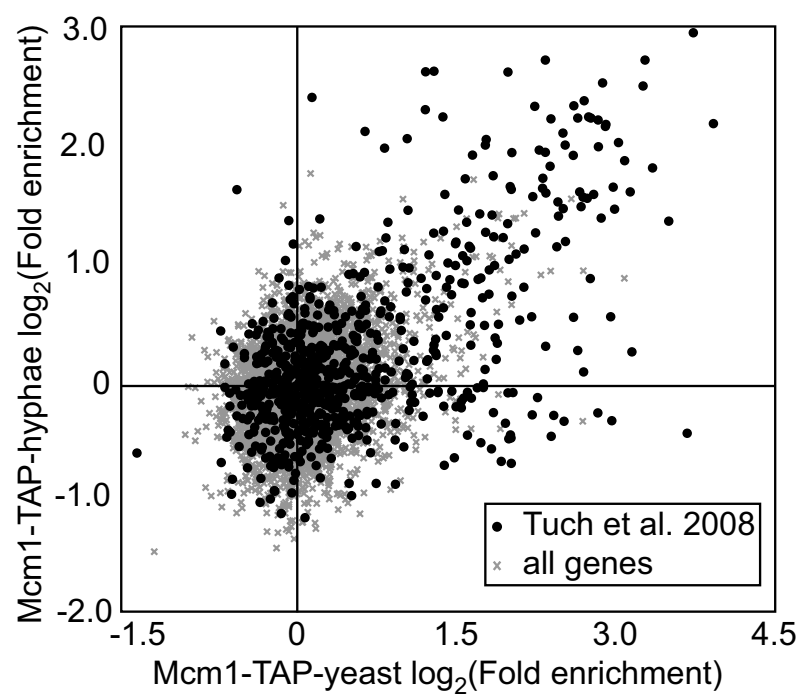

D)

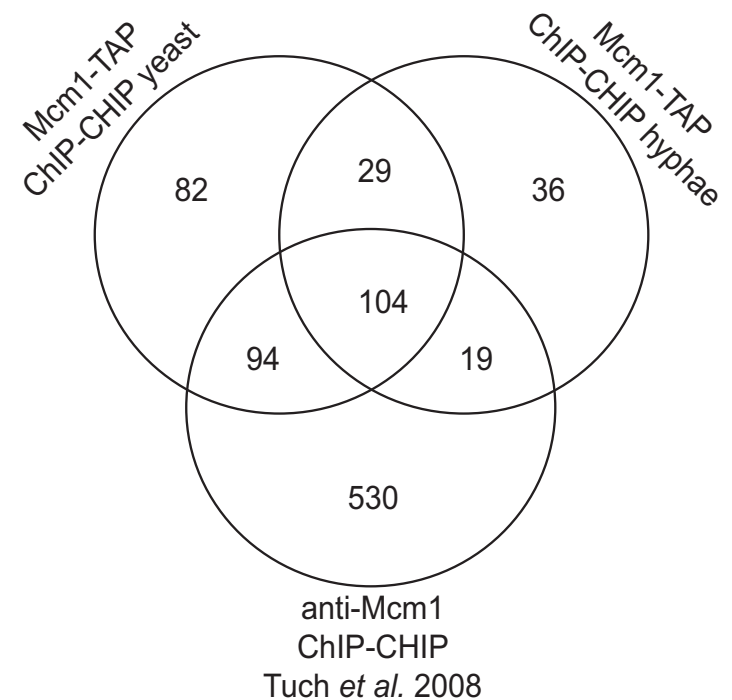

Figure 3

Validation of the CbfI, TbfI and Mcm I TAP-tagged TFs by ChIP-CHIP analysis. TbfI-HA and CbfI-HA ChIP-CHIP [20] overlaps TbfI-TAP (A) and CbfI-TAP (B) ChIP-CHIP performed with our in vivo tagged constructs. C) Comparison of Mcm I-TAP ChIP-CHIP conducted before and after the yeast to hyphal transition with the Mcm I targets derived from Tuch et al. (2008) experiments highlighted. D) Comparison of the target genes of Mcm I-TAP in yeast and hyphal states and their overlap with Tuch et al. (2008) gene list. 
a previous study revealing that $C$. albicans $\mathrm{Mcm} 1$ regulates MDR1 expression and thereby, drug resistance $[8,33]$. Indeed, a significant enrichment (7.49 fold) of $\mathrm{Mcm} 1$ binding to the promoter of the drug efflux facilitator gene MDR1 was observed in both yeast and hyphal states.

However, our data diverges from the other $\mathrm{Mcm} 1 \mathrm{ChIP}$ CHIP publications at some points. First, our results show $\mathrm{Mcm} 1$ binding in the promoters of almost all members of the pre-replication complex (Pre-RC) ( $\mathrm{Mcm}$ helicases genes MCM2/3/4/5 and 7; pvalue $=1.87 \mathrm{E}-06$; Table 2 ) while the Tuch et al. (2008) data only uncovered two members of this complex (MCM2 and 7). In addition, we detected reproducible $\mathrm{Mcm} 1$ binding at two origin-recognition-complex components (ORC1 and 3) and the loading factor for the Mcm complex, CDC6 (Table 2; see Additional file 1). Second, binding of the promoters of the cyclin genes CLN3, HGC1 and CLB3 by Mcm 1 was not detected in our experimental setup (see Additional file 1 and 2). In total, $530 \mathrm{Mcm} 1$ targets are uniquely found in the Tuch et al. gene list [8](Fig. 3D). These major differences are likely due to variations between the two independently conducted studies. Tuch and collaborators 1) treated their cells with pheromone, 2) used a polyclonal rabbit antiserum raised against an $\mathrm{Mcm} 1$ peptide, 3 ) used signal ratios of cy5 labelled IP versus cy3 labelled wholecell extract prior to performing the IP and 4) used tiling arrays to determine the promoter targets of $\mathrm{Mcm} 1$. Our procedure is somewhat different: we 1) used YPD grown cells, 2) used IgG beads-proteinA interaction to enrich target regions, 3) compared each experimental IP to a mock IP performed in untagged cells and 4) used full genome arrays with smaller coverage (about two probes/intergenic region). All these experimental changes could affect to different degrees the final result of a ChIP-CHIP. First, treating cells with pheromone might dramatically alter $\mathrm{Mcm} 1$ binding at some point in the cell cycle and pheromone response elements and deplete it at others (such as the $\mathrm{Mcm}$ complex genes). Second, polyclonal anti-Mcm1 antibodies can have cross-specificities that would not be corrected for by using the whole-cell extract as a control instead of a mock IP or an IP performed with a preimmune serum. Third, the different resolutions of the two studies could account for some overlooked targets in our experiments.

We also performed Mcm1-TAP ChIP-CHIP in the yeast to hyphal transition triggered by serum at $37^{\circ} \mathrm{C}$. $\mathrm{Mcm} 1$ was recruited to a limited set of genes (36) under these conditions (Fig. 3D). Noticeably, it was enriched in the promoters of ALS3, HWP1 and ECE1 after hyphal induction (see Additional files 1 and 2).

Thus, our genome-wide location data showed a significant consistency with previously published results on the three TFs. This suggests that our chromosomally tagged alleles are functional and that the use of a TAP-IgG pulldown protocol is applicable for ChIP-CHIP as previously reported in S. cerevisiae ${ }^{26}$ and that this protocol is comparable to a ChIP method based on a anti-HA (for Cbf1 and Tbf1) or rabbit polyclonal (for Mcm1) antibody IP.

\section{In vivo beta-galactosidase reporter assays}

The beta-galactosidase reporter system described here has already been applied to the problem of RP gene regulation in Hogues et al (2008). It allows the integration of reporter constructs in the actual chromatin environment of the gene of interest. Here, we describe its usefulness in the quantitative study of active gene loci. We produced pLYS9-lacZ and pOPI3-lacZ strains and beta-galactosidase reporter assays were performed with YPD grown cells. Our results show variable levels of reporter activity across these three promoters (Fig. 4). The multiple cloning site of our pFA-lacZ-URA3 construct allows the easy creation of various cis-regulatory mutants as examplified by the the $\mathrm{p} R P L 11$ promoter (pRPL11) [20].

\section{Conclusion}

Here, we have presented a new set of tools for functional characterization of $C$. albicans gene products by biochemical methods. We believe that the availability of such tools will greatly help future understanding of the biology of this important human pathogen.

\section{Methods}

\section{Construction of chromosomal tagging PCR cassettes}

We first adapted the S. cerevisiae PCR TAP-tagging vector pEB1340 [34] for its use in C. albicans by substituting the S. cerevisiae HIS3 marker with the C. albicans URA3, HIS1 and ARG4 genes from the previously published pFA-GFP plasmid series [26] (Fig. 1A). Subcloning of the C. albicans auxotrophic markers was done by ligation of AscI-PmeI fragments in AscI-PmeI digested pEB1340. We then derived triple HA or MYC epitope-tagging vectors in the same pFA plasmid backbones by cloning oligonucleotides encoding the HA or MYC epitope tags and containing XmaI and AscI sites (Table 3) between the XmaI and AscI sites of the pEB1340 plasmid. Auxotrophic markers URA3, HIS1 and ARG4 from plasmids pFA-XFP [26] were then subcloned into the HA and Myc constructs between AscI and PmeI.

The beta-galactosidase reporter was constructed by subcloning a PstI-MluI fragment corresponding to the Streptococcus thermophilus lacZ ORF from plasmid placpoly [35] between the PstI and AscI sites of plasmid pFA-XFP-URA3 [26].

PCR reactions were performed in $50-\mu \mathrm{l}$ volumes containing $1 \mathrm{ng}$ of plasmid template with the Expand Long Tem- 
Table 2: Mcm I-TAP targets in ChIP-CHIP analysis

\begin{tabular}{|c|c|c|c|}
\hline Systematic name & Common name & Function & Fold enrichment \\
\hline \multicolumn{4}{|c|}{ Arginine metabolism } \\
\hline orf 19.5610 & ARG3* & Ornithine carbamoyl-transferase & 2.20 \\
\hline orfl 9.4788 & ARG5,6 & Acetylglutamate kinase & 3.24 \\
\hline orfl9.3770 & ARG8* & Acetylornithine aminotransferase & 5.18 \\
\hline orfl9.2077 & $A R G 8 I *$ & Zinc-finger TF & 3.08 \\
\hline orfl 9.3934 & CARI & Arginase & 3.82 \\
\hline orfl9.3221 & CPA2* & Carbamoyl phosphate synthetase & 2.58 \\
\hline \multicolumn{4}{|l|}{ Lysine metabolism } \\
\hline orfl9.1789.1 & LYSI* & Saccharopine dehydrogenase & 5.00 \\
\hline orfl9.7448 & LYS9* & Saccharopine dehydrogenase & 2.27 \\
\hline orfl9.772 & LYS2I & Homocitrate synthase & 2.58 \\
\hline orf19.4506 & LYS22 & Homocitrate synthase & 2.57 \\
\hline orfl9.5380 & LYSI44* & Zinc cluster TF & 2.78 \\
\hline \multicolumn{4}{|l|}{ Proline catabolism } \\
\hline orfl 9.4274 & PUTI* & Proline dehydrogenase & 5.01 \\
\hline orfl9.3974 & PUT2* & I-pyrroline-5-carboxylate dehydrogenase & 2.78 \\
\hline \multicolumn{4}{|l|}{ Drug resistance } \\
\hline orfl9.5604 & $M D R I$ & $A B C$ transporter & \\
\hline \multicolumn{4}{|l|}{ Mcm complex } \\
\hline orfl9.7025 & $M C M I *$ & MADS box TF & 5.59 \\
\hline orfl 9.4354 & $M C M 2 *$ & ATP-dependent DNA helicase & 3.65 \\
\hline orfl9.1901 & MCM3 & ATP-dependent DNA helicase & 4.1 \\
\hline orfl9.376I & MCM4 & ATP-dependent DNA helicase & 3.28 \\
\hline orfl 9.5487 & MCM5 & ATP-dependent DNA helicase & 2.95 \\
\hline orfl9.201 & $M C M 7^{*}$ & ATP-dependent DNA helicase & 3.87 \\
\hline \multicolumn{4}{|c|}{ Mcm complex loading } \\
\hline orfl 9.5242 & CDC6* & ATPase helicase clamp loader & 1.79 \\
\hline \multicolumn{4}{|c|}{ Origin recognition complex (ORC) } \\
\hline orfl9.3000 & ORCI & ATPase for DNA binding & 1.67 \\
\hline orfl9.6942 & ORC3 & ATPase & 1.81 \\
\hline
\end{tabular}

* Genes in common with ChIP-CHIP data of Tuch et al., (2008) using tiling array. 
A)

C)

In vivo reporter integration

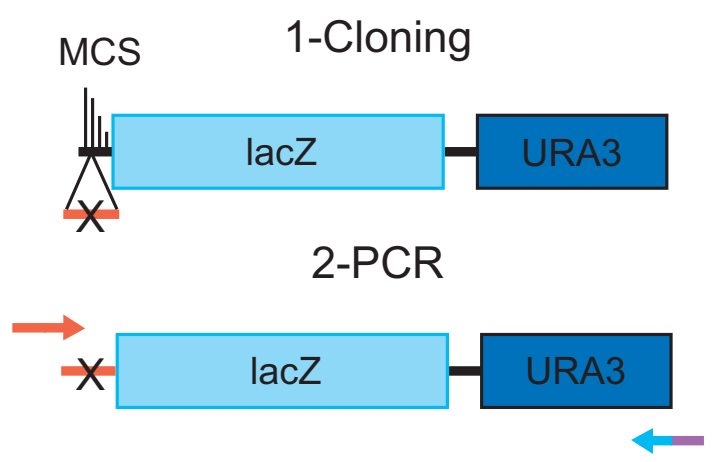

3-Homologous recombination
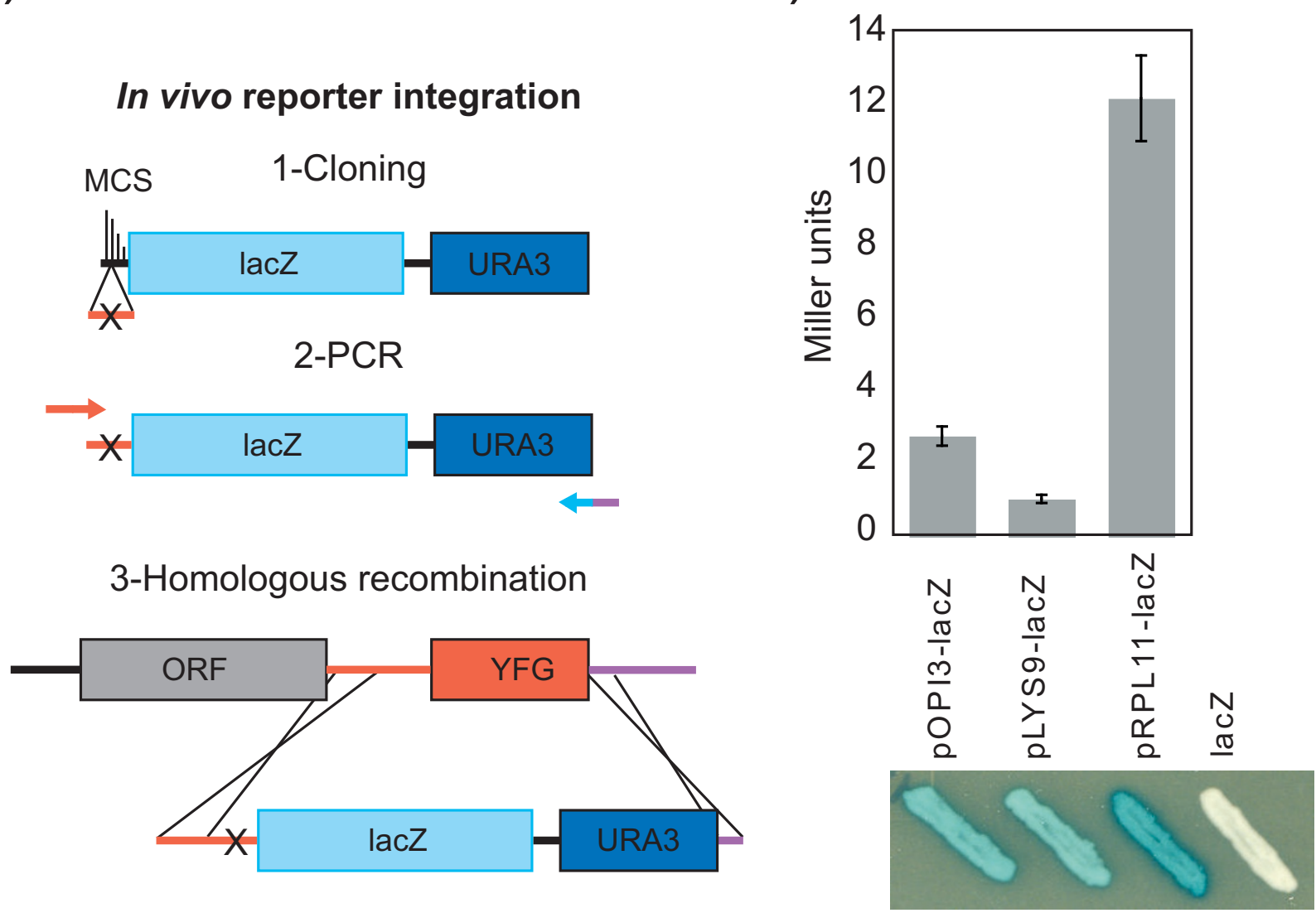

B)

\section{PCR confirmation}

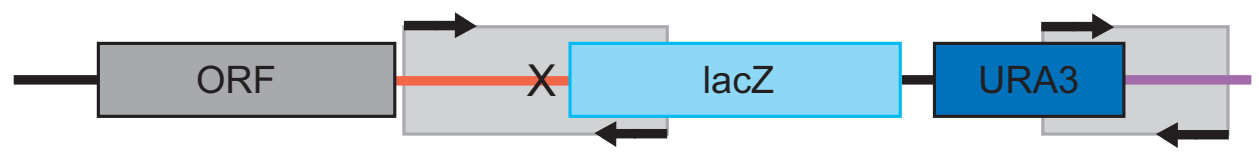

Figure 4

A new reporter construct allowingin vivo analysis of gene expression inC. albicans. A) Gene replacement by betagalactosidase following I- wild-type or mutant promoter cloning, 2- PCR amplification of the promoter-lacZ fusion and 3- in vivo gene replacement by transformation and homologous recombination. B) PCR confirmation of our in vivo inserted betagalactosidase constructs. C) Beta-galactosidase activity of the promoters of the OPI3, LYS9 and RPLI I genes. YFG stands for Your Favorite Gene.

plate polymerase following manufacturer's instructions (Roche, Germany). PCR parameters were 1 cycle at $94^{\circ} \mathrm{C}$, 5 min followed by 35 cycles at $94^{\circ} \mathrm{C}, 30 \mathrm{sec} ; 58^{\circ} \mathrm{C}, 1 \mathrm{~min}$; $68^{\circ} \mathrm{C}, 3 \mathrm{~min}$.

\section{Construction of $\mathrm{C}$. albicans epitope-tagged strains}

Cell growth, transformation, and DNA preparation were carried out using standard procedures $[26,36]$. Transformants were selected on either of -Ura, -His or -Arg selective plates. Correct integration was verified by PCR, sequencing and finally Western blotting (Fig. 1A). Rate of correct integration was comparable to a previous study using sim- 
Table 3: Primers used for in this study

\begin{tabular}{|c|c|}
\hline Name & Sequence \\
\hline HA_F & $\begin{array}{l}\text { CCGGGTACCCATACGATGTTCCTGACTATGCGGGCTATCCCTATGACGTCCCGGACTATGCAGGATATCCATATGACGTTCC } \\
\text { AGATTACGCTTAGGG }\end{array}$ \\
\hline HA_R & $\begin{array}{l}\text { CGCGCCCTAAGCGTAATCTGGAACGTCATATGGATATCCTGCATAGTCCGGGACGTCATAGGGATAGCCCGCATAGTCAGGA } \\
\text { ACATCGTATGGGTAC }\end{array}$ \\
\hline 5MYC_F & $\begin{array}{l}\text { CCGGGGAACAGAAGCTTATATCCGAAGAAGACCTCGGAGAGCAAAAGCTCATTTCAGAAGAGGATCTAGGCGAACAGAAAC } \\
\text { TAATCTCGGAGGAGGACCTCGGTGAACAAAAGCTTATCTCTGAGGAAGATCTTGGCGAGCAGAAGCTCATATCAGAGGAAGA } \\
\text { CCTAGGG TAG GG }\end{array}$ \\
\hline 5MYC_R & $\begin{array}{l}\text { CGCGCCCTACCCTAGGTCTTCCTCTGATATGAGCTTCTGCTCGCCAAGATCTTCCTCAGAGATAAGCTTTTGTTCACCGAGGT } \\
\text { CCTCCTCCGAGATTAGTTTCTGTTCGCCTAGATCCTCTTCTGAAATGAGCTTTTGCTCTCCGAGGTCTTCTTCGGATATAAGC } \\
\text { TTCTGTTCC }\end{array}$ \\
\hline Nop I-TAP_F & $\begin{array}{l}\text { AGAAGAAAGAATTAAACCATTGGAACAATTGACCTTGGAACCTTATGAAAGAGACCATTGTATTGTTGTTGGTAGATACATGA } \\
\text { GAAGCGGAATAAAGAAAGGT CGA CGG ATC CCC GGG TT }\end{array}$ \\
\hline NopI-TAP_R & $\begin{array}{l}\text { TAGAGTTGATTAGACCTTATTGTTTTATTTTTTCATTTTATTATATATGTCGTATCTTACAGTTCTTTAAATACCAGTGTTTCCAAA } \\
\text { ATTTTCATTCATTCTCG ATG AAT TCG AGC TCG TT }\end{array}$ \\
\hline Cbfl-TAP_F & $\begin{array}{l}\text { TGAACAAGCTGTTAGTGAATTGAGTGCTTCAAATGAGAAATTGAAACATGAATTAGAATCAGCTTATCGTGAAATCGAACAATT } \\
\text { GAAGAGAGGGAAGAAAGGT CGA CGG ATC CCC GGG TT }\end{array}$ \\
\hline Cbfl-TAP_R & $\begin{array}{l}\text { TAACATAATTTCAAATACCGAGTAGGAATACACAACCCCAACATCTAACCAGCCATACATTTACATATTTATAATTACATATTA } \\
\text { AAACATCGTCAAATTAATCG ATG AAT TCG AGC TCG TT }\end{array}$ \\
\hline Tbfl-TAP_F & $\begin{array}{l}\text { AACAACAAGAGAAAGAACAACCGGATCAGCAACAACCAGATCAACAACACCCAGATCGACAACAACAAGAGCAGATCCAAC } \\
\text { AACCAGAAAATCTGGATAAAGGT CGA CGG ATC CCC GGG TT }\end{array}$ \\
\hline Tbfl-TAP_R & $\begin{array}{l}\text { ATCAACTATTGTGATCCTGCTTAAGTTAGCTTGAACAATTATTCAAATCAATTTACACCTTAAAGATAGATTAATTAACAATACA } \\
\text { AATATAATGCTACATGTCG ATG AAT TCG AGC TCG TT }\end{array}$ \\
\hline Mcml-TAP_F & $\begin{array}{l}\text { ACATCAACCTGGTATTCCATTACAAGGTGGTTATAGTGATCAATACCTGTATTTTGGTAATATTCAAAATAACAACATACCTAA } \\
\text { TCAACAGCAATATCAAGGTCGACGGATCCCCGGGTT }\end{array}$ \\
\hline Mcml-TAP_R & $\begin{array}{l}\text { ATTATTCACCTAAATCCCCTGACCTCTGGCCAAACACTTTTCTTTGTAGATGGGAGGGGAGCGGGGGGAGGAAATGAAAAACC } \\
\text { ATTGGCAACGAGAAAAAGATCGATGAATTCGAGCTCGTT }\end{array}$ \\
\hline Nopl_confirm_F & AATCATAGATGATGCTAGACATCC \\
\hline Nopl_confirm_R & TGTTGGGTCTAAAGGTCAAAGTGC \\
\hline Cbfl_confirm_F & AAGAGAATCCATAAATACTGG \\
\hline Cbfl_confirm_R & CTTTGATACCCCTAATGTTTC \\
\hline Tbfl_confirm_F & AAGCGGTTTGGAAATTCCTAG \\
\hline Tbfl_confirm_R & TTGCATGTTAAAATTCGTCTC \\
\hline Mcml_confirm_F & TGACGATGGTACTTCTCAAGGT \\
\hline Mcml_confirm_R & AATTGTTTCAACATTTTGGTTTTT \\
\hline TAP-HA_F & GGT CGA CGG ATC CCC GGG TTA TAC CCA TAC GAT GTT CCT GAC \\
\hline TAP-MYC_F & GGT CGA CGG ATC CCC GGG TTA GAA CAG AAG CTT ATA TCC GAA \\
\hline TAP-HA-MYC_R & TCG ATG AAT TCG AGC TCG TT \\
\hline
\end{tabular}


ilar condiitons and was in the range of $40-80 \%$ depending on the gene locus considered [26]. We used this strategy to C-terminally fuse Tbf1, Cbf1 and Mcm1 with a TAP tag and to introduce an HA or a MYC tag to the C-terminus of Tbf1 and Cbf1.

\section{Western blotting}

Whole cell extracts were obtained by boiling cells at 2 ODs in loading buffer with $100 \mathrm{mM}$ DTT for 10 minutes. Proteins were then separated on a 10\% SDS-PAGE gel and transferred to a PVDF membrane (Millipore). Antibodies were prepared in TBS-0.05\% Tween 20 5\% skim milk powder. A rabbit polyclonal antibody directed against the TAP-tag (Open Biosystems) was used at $0.5 \mu \mathrm{g} / \mathrm{ml}$ while monoclonal antibodies anti-HA (12CA5) and anti-Myc (9E10) were used at $5 \mu \mathrm{g} / \mathrm{ml}$. HRP-conjugated goat antirabbit and anti-mouse secondary antibodies (Santa Cruz) were used at $0.04 \mu \mathrm{g} / \mathrm{ml}$. The HRP signal was revealed with Immobilon ${ }^{\mathrm{TM}}$ HRP substrate (Millipore).

\section{TAP purifications and mass spectrometry}

Tandem affinity purifications were performed as described http://depts.washington.edu/yeastrc/pages/ plasmids.html and then precipitated with Trichloroacetic acid (TCA). For mass spectrometry analysis of the TAP purified proteins, the digestion was performed using Trypsin (Promega) in $50 \mathrm{mM}$ ammonium bicarbonate for 4 hours at $37^{\circ} \mathrm{C}$ and dried down. One quarter of the TCA precipitate was loaded on a $10 \%$ SDS-PAGE gel. The gel was stained with SYPRO Ruby according to manufacturer's instructions (Invitrogen). Excised protein bands were processed as described [37]. Samples were resolubilized in $5 \%$ acetonitrile $0.2 \%$ formic acid and analyzed on a Eksigent nanoLC system coupled to a Thermo LTQOrbitrap MS instrument with a home-made C18 pre-column $(5 \mathrm{~mm} \times 300 \mathrm{um})$ and an analytical column $(10 \mathrm{~cm}$ $\times \mathrm{mm} \times 300 \mathrm{~m}$ i.d. Jupiter $3 \mathrm{~m} \mathrm{C18}$ ). Sample injection was $10 \mathrm{ul}$. The digest was first loaded on the pre-column at a flow rate of $4 \mathrm{ul} / \mathrm{min}$ and subsequently eluted onto the analytical column using a gradient from $10 \%$ to $60 \%$ aqueous acetonitrile $(0.2 \%$ formic acid) over $56 \mathrm{~min}$ at $600 \mathrm{nl} / \mathrm{min}$. Database searches were performed against a non-redundant fungal database using Mascot version 2.1 (Matrix Science).

\section{ChIP-CHIP analysis of TbfI, CbfI and Mcm Iby TAP-IgG pull-down in C. albicans}

Chromatin immunoprecipitation (ChIP) experiments were performed with chromosomally tagged Tbf1-TAP, Cbf1-TAP and Mcm1-TAP as described [20]. Cells were grown to an optical density at $600 \mathrm{~nm}$ of 0.6 in $50 \mathrm{ml}$ of YPD or YPD with $10 \%$ FBS for Mcm1-TAP in hyphal state. We followed the ChIP protocol available at http:// www.ircm.qc.ca/microsites/francoisrobert/en/317.html with the following exceptions: chromatin was sonicated to an average $300 \mathrm{bp}$, and $700 \mu \mathrm{l}$ of whole-cell extract (WCE) were incubated with IgG-Sepharose beads (GE Healthcare). Tagged ChIPs were labeled with Cy5 dye and untagged (mock) ChIPs were labeled with Cy3 dye and were then co-hybridized to our full-genome arrays.

\section{Candida albicans full-genome arrays, hybridization, scanning and normalization}

Our C. albicans full-genome microarrays contain single spots of 5,423 intergenic 70-mer oligonucleotide probes combined with 6,394 intragenic 70-mer oligonucleotide probes already in use in our C. albicans ORF microarray $[20,38]$. We designed the 5,423 probes that correspond to the promoter regions of most of the genes in the C. albicans Genome Assembly 21 by using the same algorithm that was successfully applied to the development of our $C$. albicans ORF oligonucleotide arrays with added weight provided for regions of high homology among Candida species. Our lab has developed full-genome (ORF and intergenic) arrays for use in location profiling experiments and the DNA microarrays were processed and analysed as previously described [20].

\section{Nucleotide sequence accession numbers}

The sequences of plasmids pFA-TAP-URA3, pFA-TAPHIS1， pFA-TAP-ARG4， pFA-HA-URA3， pFA-HA-HIS1, pFA-HA-ARG4, pFA-MYC-URA3, pFA-MYC-HIS1, pFAMYC-ARG4 and pFA-LacZ-URA3 have been submitted to GenBank and have been assigned the following accession numbers: FJ160456, FJ160457， FJ160458, FJ160464, FJ160462, FJ160463, FJ160460, FJ160461, FJ160459 and F]160455, respectively.

\section{Authors' contributions}

HL carried out cloning procedures, HA, MYC and TAP tagging of Cbf1 and Tbf1 in C. albicans, immunoblots, tagging and affinity purification of NOP1-TAP, ChIP-CHIP of Cbf1-TAP and Tbf1-TAP as well as lacZ reporter assays. AS and CA constructed the Mcm1-TAP C. albicans strain and performed ChIP-CHIP of Mcm1-TAP in both yeast and hyphal states. AN and MW oversaw the work. The first draft of the article was written by HL and AS. All authors read and approved the final manuscript.

\section{Additional material}

\section{Additional file 1}

Promoter targets of Mcm1 in our and Tuchet al. (2008) data. The data provided represent gene promoter bound by $\mathrm{Mcm} 1$ in both yeast and hyphae conditions. Tuch et al. (2008) Mcm1 binding dataset was also included.

Click here for file

[http://www.biomedcentral.com/content/supplementary/14712164-9-578-S1.xls] 


\section{Additional file 2}

Mcm1-TAP ChIP-CHIP fold changes in yeast and hyphal states. This file contains the complete data of Mcm1 ChIP-CHIP experiment performed in this study.

Click here for file

[http://www.biomedcentral.com/content/supplementary/14712164-9-578-S2.xls]

\section{Acknowledgements}

Thanks to Eric Bonneil and Pierre Thibeault for expert help in mass spectrometry processing of samples and data analysis. Thanks to E. O'Shea, J. Weissman and J. Wendland for providing plasmid constructs. This work was supported by a grant from Canadian Institute for Health Research (ClHR) to MW and AN (MOP-8434I). HL was supported by $\mathrm{NCIC}$ grant 17134, AS was supported by a CIHR postdoctoral fellowship and CA by an Alexander Graham Bell CGS-NSERC scholarship. This is NRC manuscript \#49576.

\section{References}

I. Berman J, Sudbery PE: Candida Albicans: a molecular revolution built on lessons from budding yeast. Nature reviews 2002, 3(12):918-930.

2. Pappas PG, Rex JH, Lee J, Hamill RJ, Larsen RA, Powderly W, Kauffman CA, Hyslop N, Mangino JE, Chapman S, et al.: A prospective observational study of candidemia: epidemiology, therapy, and influences on mortality in hospitalized adult and pediatric patients. Clin Infect Dis 2003, 37(5):634-643.

3. Colombo AL, Perfect J, DiNubile M, Bartizal K, Motyl M, Hicks P, Lupinacci R, Sable C, Kartsonis N: Global distribution and outcomes for Candida species causing invasive candidiasis: results from an international randomized double-blind study of caspofungin versus amphotericin B for the treatment of invasive candidiasis. Eur J Clin Microbiol Infect Dis 2003, 22(8):470-474.

4. Kontoyiannis DP, Lewis RE: Antifungal drug resistance of pathogenic fungi. Lancet 2002, 359(93 I 2): I I35-I I 44.

5. Jiang B, Xu D, Allocco J, Parish C, Davison J, Veillette K, Sillaots S, Hu W, Rodriguez-Suarez R, Trosok S, et al:: PAP Inhibitor with In Vivo Efficacy Identified by Candida albicans Genetic Profiling of Natural Products. Chem Biol 2008, 15(4):363-374.

6. Rodriguez-Suarez R, Xu D, Veillette K, Davison J, Sillaots $S$, Kauffman S, Hu W, Bowman J, Martel N, Trosok S, et al.: Mechanism-ofaction determination of GMP synthase inhibitors and target validation in Candida albicans and Aspergillus fumigatus. Chem Biol 2007, I 4(10): I 163-1 I75.

7. Xu D, Jiang B, Ketela T, Lemieux S, Veillette K, Martel N, Davison J, Sillaots S, Trosok S, Bachewich C, et al.: Genome-wide fitness test and mechanism-of-action studies of inhibitory compounds in Candida albicans. PLoS Pathog 2007, 3(6):e92.

8. Tuch BB, Galgoczy DJ, Hernday AD, Li H, Johnson AD: The evolution of combinatorial gene regulation in fungi. PLoS Biol 2008, 6(2):e38.

9. Selmecki A, Forche A, Berman J: Aneuploidy and isochromosome formation in drug-resistant Candida albicans. Science 2006, 3 I3(5785):367-370.

10. Whiteway M, Bachewich C: Morphogenesis in Candida albicans. Annu Rev Microbiol 2007, 61:529-553.

11. Noble SM, Johnson AD: Genetics of Candida albicans, a diploid human fungal pathogen. Annu Rev Genet 2007, 41:193-211.

12. Krogan NJ, Cagney G, Yu H, Zhong G, Guo X, Ignatchenko A, Li J, Pu S, Datta N, Tikuisis AP, et al.: Global landscape of protein complexes in the yeast Saccharomyces cerevisiae. Nature 2006, 440(7084):637-643

13. Krogan NJ, Peng WT, Cagney G, Robinson MD, Haw R, Zhong G, Guo X, Zhang X, Canadien V, Richards DP, et al.: High-definition macromolecular composition of yeast RNA-processing complexes. Molecular cell 2004, I3(2):225-239.
14. van Steensel B: Mapping of genetic and epigenetic regulatory networks using microarrays. Nature genetics 2005, 37(Suppl):SI8-24.

15. Harbison CT, Gordon DB, Lee TI, Rinaldi NJ, Macisaac KD, Danford TW, Hannett NM, Tagne JB, Reynolds DB, Yoo J, et al:: Transcriptional regulatory code of a eukaryotic genome. Nature 2004, 43 I (7004):99-104.

16. Lee TI, Rinaldi NJ, Robert F, Odom DT, Bar-Joseph Z, Gerber GK, Hannett NM, Harbison CT, Thompson CM, Simon I, et al.: Transcriptional regulatory networks in Saccharomyces cerevisiae. Science (New York, NY) 2002, 298(5594):799-804.

17. Zordan RE, Miller MG, Galgoczy DJ, Tuch BB, Johnson AD: Interlocking transcriptional feedback loops control white-opaque switching in Candida albicans. PLoS Biol 2007, 5( I0):e256.

18. Buck MJ, Lieb JD: ChIP-chip: considerations for the design, analysis, and application of genome-wide chromatin immunoprecipitation experiments. Genomics 2004, 83(3):349-360.

19. Tsong $A E$, Tuch $B B$, $\mathrm{Li} \mathrm{H}$, Johnson $A D$ : Evolution of alternative transcriptional circuits with identical logic. Nature 2006, 443(7I I 0):4I5-420.

20. Hogues H, Lavoie H, Sellam A, Mangos M, Roemer T, Purisima E, Nantel A, Whiteway M: Transcription factor substitution during the evolution of fungal ribosome regulation. Molecular cell 2008, 29(5):552-562.

21. Coste A, Selmecki A, Forche A, Diogo D, Bougnoux ME, d'Enfert C, Berman J, Sanglard D: Genotypic evolution of azole resistance mechanisms in sequential Candida albicans isolates. Eukaryot Cell 2007, 6(10): 1889-1904.

22. Coste A, Turner V, Ischer F, Morschhauser J, Forche A, Selmecki A, Berman J, Bille J, Sanglard D: A mutation in Taclp, a transcription factor regulating CDRI and CDR2, is coupled with loss of heterozygosity at chromosome 5 to mediate antifungal resistance in Candida albicans. Genetics 2006, I 72(4):2139-2156.

23. Nobile CJ, Mitchell AP: Regulation of cell-surface genes and biofilm formation by the $\mathrm{C}$. albicans transcription factor Bcrlp. Curr Biol 2005, I 5(I 2): I I50-I I 55.

24. Noble SM, Johnson AD: Strains and Strategies for Large-Scale Gene Deletion Studies of the Diploid Human Fungal Pathogen. Eukaryotic Cell 2005.

25. Wilson RB, Davis D, Mitchell AP: Rapid hypothesis testing with Candida albicans through gene disruption with short homology regions. J Bacteriol I999, I8 I(6): |868-1874

26. Gola S, Martin R, Walther A, Dunkler A, Wendland J: New modules for PCR-based gene targeting in Candida albicans: rapid and efficient gene targeting using 100 bp of flanking homology region. Yeast (Chichester, England) 2003, 20(16):1339-1347.

27. Jarvik JW, Telmer CA: Epitope tagging. Annu Rev Genet 1998, 32:601-618.

28. Brizzard B: Epitope tagging. Biotechniques 2008, 44(5):693-695.

29. Rigaut G, Shevchenko A, Rutz B, Wilm M, Mann M, Seraphin B: A generic protein purification method for protein complex characterization and proteome exploration. Nat Biotechnol 1999, I7(10): 1030-1032

30. Gavin AC, Aloy P, Grandi P, Krause R, Boesche M, Marzioch M, Rau $C$, Jensen LJ, Bastuck S, Dumpelfeld B, et al:: Proteome survey reveals modularity of the yeast cell machinery. Nature 2006, 440(7084):63I-636.

3I. Gavin AC, Bosche M, Krause R, Grandi P, Marzioch M, Bauer A, Schultz J, Rick JM, Michon AM, Cruciat CM, et al.: Functional organization of the yeast proteome by systematic analysis of protein complexes. Nature 2002, 4I5(6868): |4|-|47.

32. Collins SR, Kemmeren P, Zhao XC, Greenblatt JF, Spencer F, Holstege FC, Weissman JS, Krogan NJ: Toward a comprehensive atlas of the physical interactome of Saccharomyces cerevisiae. Mol Cell Proteomics 2007, 6(3):439-450.

33. Riggle PJ, Kumamoto CA: Transcriptional regulation of MDR I, encoding a drug efflux determinant, in fluconazole-resistant Candida albicans strains through an $\mathrm{Mcm} / \mathrm{p}$ binding site. Eukaryot Cell 2006, 5(I 2): 1957-1968.

34. Ghaemmaghami S, Huh WK, Bower K, Howson RW, Belle A, Dephoure N, O'Shea EK, Weissman JS: Global analysis of protein expression in yeast. Nature 2003, 425(6959):737-74I.

35. Munro CA, Selvaggini S, de Bruijn I, Walker L, Lenardon MD, Gerssen B, Milne S, Brown AJ, Gow NA: The PKC, HOG and Ca2+ signal- 
ling pathways co-ordinately regulate chitin synthesis in Candida albicans. Molecular microbiology 2007, 63(5):|399-|4|3.

36. Ausubel FM, Brent R, Kingston RE, Moore DD, Seidman JG, Smith JA, $\mathrm{K} \mathrm{S}$ : Current protocols in molecular biology. Volume 2. New York: John Wiley and Sons; 1992.

37. Smith CA, Lau KM, Rahmani Z, Dho SE, Brothers G, She YM, Berry DM, Bonneil E, Thibault P, Schweisguth F, et al:: aPKC-mediated phosphorylation regulates asymmetric membrane localization of the cell fate determinant Numb. The EMBO journal 2007, 26(2):468-480.

38. Nantel A, Rigby T, Hogues $\mathrm{H}$, Whiteway M: Microarrays for studying pathology in Candida albicans. In Medical Mycology: Cellular and Molecular Techniques Edited by: Kavanaugh K. Wiley Press; 2006.

Publish with Bio Med Central and every scientist can read your work free of charge

"BioMed Central will be the most significant development for disseminating the results of biomedical research in our lifetime. "

Sir Paul Nurse, Cancer Research UK

Your research papers will be:

- available free of charge to the entire biomedical community

- peer reviewed and published immediately upon acceptance

- cited in PubMed and archived on PubMed Central

- yours - you keep the copyright

Submit your manuscript here:

http://www.biomedcentral.com/info/publishing_adv.asp
BioMedcentral 